\title{
BIOSTRATIGRAPHY AND BIOGEOGRAPHY OF FRASNIAN, UPPER DEVONIAN CONODONTS
}

KLAPPER, Gilbert, Dept. of Geology, University of Iowa, Iowa City, IA 52242, U.S.A.

Analysis of Frasnian conodont sequences in the Montagne Noire, southern France, results in the recognition of a conventional zonation consisting of thirteen zones. Graphic correlation of eight Montagne Noire sections with a total of 11 sections in the Alberta Rockies, the Hay River-Trout River areas of the southern Northwest Territories, Canada, the Midcontinent and New York sequences in the United States, and the Canning Basin, Western Australia divides the Frasnian into 34 composite standard units. Most of these sections are dominated by conodonts of the outer-shelf to basinal Palmatolepis biofacies, but those of Hay River-Trout River are occupied by the quite contrasting inner-shelf Polygnathus biofacies. Correlation of the latter with the Montagne Noire zonation is effected only through graphic correlation. The taxonomy of many of the critical species involved in the correlations is based on shape analysis and multielement taxonomy of Palmatolepis.

Prevailing opinion is that the Frasnian was a time of cosmopolitanism as exemplified both by benthic organisms, especially corals and brachiopods, as well as conodonts. This contrasts with the Early and Middle Devonian which was a time of significant endemism in benthic fossils and in conodonts. The high point in conodont endemism according to the zone-by-zone analysis of the Early and Middle Devonian (Klapper and Johnson, 1980) was the early Eifelian when there were about $70 \%$ endemic species. Although endemism did not reach this high in the Frasnian, analysis of a limited number of intensively collected and studied sections in the Montagne Noire, U.S. and Canada, Western Australia, and the Russian Platform demonstrates levels of endemism ranging from about 30 to $45 \%$ in three composites of two zones each. Endemic species occur in both the Palmatolepis and Polygnathus biofacies. Using the Probabilistic Index of Similarity of Raup and Crick (1979), the null hypothesis of randomness is rejected for some paired comparisons between localities representing different biofacies, as would be expected, but it is also rejected between some localities representing the same biofacies on different continents. Although the explanation of significantly dissimilar faunas can be accepted at $95 \%$ confidence levels in only a limited number of instances, there are dissimilarities of somewhat lesser magnitude among various paired comparisons. This seems to indicate that the Frasnian was not a time of conodont cosmopolitanism even within the Palmatolepis biofacies. 